University of Nebraska - Lincoln

DigitalCommons@University of Nebraska - Lincoln

USDA Wildlife Services - Staff Publications

U.S. Department of Agriculture: Animal and Plant Health Inspection Service

2011

Fifteen Years of Urban Deer Management: The Fontenelle Forest Experience

\author{
Scott E. Hygnstrom \\ University of Nebraska-Lincoln, shygnstrom1@unl.edu \\ Gary W. Garabrandt \\ Fontenelle Nature Association \\ Kurt C. Vercauteren \\ USDA-APHIS-Wildlife Services, kurt.c.vercauteren@usda.gov
}

Follow this and additional works at: https://digitalcommons.unl.edu/icwdm_usdanwrc

Hygnstrom, Scott E.; Garabrandt, Gary W.; and Vercauteren, Kurt C., "Fifteen Years of Urban Deer Management: The Fontenelle Forest Experience" (2011). USDA Wildlife Services - Staff Publications. 1362.

https://digitalcommons.unl.edu/icwdm_usdanwrc/1362

This Article is brought to you for free and open access by the U.S. Department of Agriculture: Animal and Plant Health Inspection Service at DigitalCommons@University of Nebraska - Lincoln. It has been accepted for inclusion in USDA Wildlife Services - Staff Publications by an authorized administrator of DigitalCommons@University of Nebraska - Lincoln. 


\title{
Fifteen Years of Urban Deer Management: The Fontenelle Forest Experience
}

\author{
SCOTT E. HYGNSTROM, ${ }^{1}$ School of Natural Resources, 415 Hardin Hall, University of Nebraska, Lincoln, NE 68583-0974, USA \\ GARY W. GARABRANDT, Fontenelle Nature Association, 1111 N Bellevue Boulevard, Bellevue, NE 68005, USA \\ KURT C. VERCAUTEREN, National Wildlife Research Center, United States Department of Agriculture-Animal and Plant Health Inspection \\ Service-Wildlife Services, 4101 LaPorte Avenue, Fort Collins, CO 80521-2154, USA
}

\begin{abstract}
Fontenelle Forest $(\mathrm{FF})$ is a $16.5-\mathrm{km}^{2}$ serene natural area surrounded by a developed landscape, including Omaha and Bellevue, Nebraska, USA. An overabundant population of white-tailed deer (Odocoileus virginianus) degraded the local forest. In January 1995, we estimated the density of deer at $27 \mathrm{deer} / \mathrm{km}^{2}$ in FF and the adjacent Gifford Point Wildlife Management Area (GP) and Bellevue residential (BR) area. We engaged in a public process to establish a deer management program in this developed landscape and learned from 15 years of experience. Formation of the Bellevue Deer Task Force led to implementation of controlled deer-hunting seasons from 1996 to present. Total annual harvest of whitetailed deer by archery and muzzleloader hunters at FF ranged from 28 in 1996 to 140 in 2006. Mean success rates of archery (52\%) and muzzleloader hunters (93\%) at FF were high compared to other areas. Densities of white-tailed deer in the study area declined from $27 \mathrm{deer} / \mathrm{km}^{2}$ in 1995 to $15 \mathrm{deer} / \mathrm{km}^{2}$ in 2006, though harvest and deer were not evenly distributed across the landscape. By 2006, densities of deer were near overwinter goals in the hunted FF lowlands, FF uplands, and GP lowlands $\left(7 \mathrm{deer} / \mathrm{km}^{2}, 5 \mathrm{deer} / \mathrm{km}^{2}\right.$, and $13 \mathrm{deer} / \mathrm{km}^{2}$, respectively), but they remained relatively high in the adjacent unhunted BR area (30 deer/ $\mathrm{km}^{2}$ ). Native plant communities were severely overbrowsed in the study area through 1995 , influencing their structure and composition, but signs of recovery were apparent in areas where controlled hunting reduced densities of deer to $<6$ deer $/ \mathrm{km}^{2}$. Controlled hunts at FF have reduced densities of deer in the immediate area to tolerable levels and have been accepted by area residents, with relatively little media coverage and public scrutiny. Total costs of controlled (US\$120/deer) and depredation hunts (US\$70/deer, 2010 prices) were low compared to other areas and methods. Common themes of the 15-year management program included cooperation, communication, leadership, research-based management, adaptive management, persistence, and resources. (C) 2011 The Wildlife Society.
\end{abstract}

KEY WORDS deer-human interactions, developed environments, Odocoileus virginianus, white-tailed deer, wildlife damage management.

The presence of white-tailed deer (Odocoileus virginianus) in developed landscapes is a considerable problem in North America (Swihart et al. 1995, Kilpatrick and Walter 1997, DeNicola et al. 2000). Problems associated with deer, such as damage to personal property and plant communities (Connelly et al. 1987, Stromayer and Warren 1997, Waller and Alverson 1997), deer-vehicle collisions (DVCs; Bashore et al. 1985, Etter et al. 2002, Sudharsan et al. 2009), and disease transmission (Ginsberg and Zhioua 1999, Joly et al. 2006, Miller et al. 2007) have created demand for research and management. During the 1990s, these problems developed in Fontenelle Forest Nature Preserve (FF), Gifford Point Wildlife Management Area (GP), and the residential area and adjacent parks along the Missouri River, near Omaha and Bellevue, Nebraska, USA

Received: 7 January 2011; Accepted: 29 July 2011

${ }^{1}$ E-mail: shygnstrom1@unl.edu
(BR area). In particular, DVCs in Bellevue and Sarpy County increased $325 \%$ and $192 \%$, respectively, from 1984 to 1994 (8 to 34 and 63 to 184 , respectively; G. Garabrandt, Fontenelle Nature Association [FNA], unpublished data).

In 1992, noted conservation biologist Jared Diamond visited FF and, while impressed with its overall beauty, was dismayed by the ecological condition of the forest. Diamond (1992: pages 2-3) noted that overabundant white-tailed deer were degrading the forest and causing "reverse succession." Persistent browsing by deer was preventing regeneration of overstory species such as bur oak (Quercus macrocarpa), shagbark hickory (Carya ovata), and American linden (Tilia americana). These climax species were being replaced by hackberry (Celtis occidentalis) and ironwood (Ostrya virginiana). Deer-resistant snakeroot (Sanicula spp.), barberry (Berberis thunbergii), and tree of heaven (Ailanthus altissima) were increasing, while less resistant native woodland forbs were disappearing. 
Aerial counts of FF and GP in $1965(n=161$ deer $)$ and 1982 ( $n=158$ deer $)$ revealed that deer primarily were distributed in the GP lowlands during winter (N. Dey, Nebraska Game and Parks Commission [NGPC], personal communication). Managers speculated that the population of white-tailed deer increased dramatically in the late 1980s due to decreased hunting and increased anthropomorphic food associated with the increasing housing density. In addition, it appeared that individual deer shifted their home ranges into the wooded uplands of $\mathrm{FF}$ and adjacent residential areas, and deer began to populate subdivisions of the BR area. By the mid 1990s, it was clear that the deer problem was spatially and logistically broader than FF could solve on its own.

The Bellevue Deer Task Force (BDTF) was formed in March 1994 and consisted of city and county officials, local residents and landowners, FF and NGPC staff, and other personnel from natural resource agencies. The BDTF met monthly to evaluate ecological, environmental, and sociological impacts of white-tailed deer in the area; develop program objectives; review management options; and resolve problems with the perceived overabundant population of whitetailed deer. Decisions were made to implement a public information program, research projects, and controlled hunting seasons on white-tailed deer in the area. In mid-1995, the BDTF recommended conducting a controlled public hunt in FF. The FF Land Management Committee and Board voted to implement annual managed deer hunts with the goal of reducing the population of white-tailed deer to a level that would allow the habitat to recover to its former health and diversity. During the following 15 years, Gary Garabrandt, Ranger of FF, served as the administrator of these annual hunts, became an expert in managing controlled deer hunts, and responded to requests from land managers across the nation on details of the successful program.

Management of wildlife often is more an application of human dimensions than wildlife science, and case studies are uncommon in the wildlife-related scientific literature (Kilpatrick et al. 1997). Here, we present our experience with management of white-tailed deer at FF as a case study of human and deer management. Our objectives were to 1) outline the deer management program at $\mathrm{FF}, 2$ ) report on outcomes of the program, and 3) provide recommendations for developing and implementing effective deer management programs in developed landscapes.

\section{STUDY AREA}

Our study area was bounded on the east by the Missouri River, the north by the city of Omaha, and on the west and south by the city of Bellevue (Fig. 1). The study area consists of 4 geographically distinct areas, including FF lowland, FF upland, GP lowland, and the BR area. Fontenelle Forest was a 738-ha privately owned natural area and conservation education facility that consisted of forested floodplain ( $357 \mathrm{ha})$ and wooded uplands (381 ha). Fontenelle Forest was traversed by $27 \mathrm{~km}$ of hiking trails. Public recreation and environmental education were the primary land uses, with nearly 60,000 visitors annually. Prior to our efforts, hunting had not been

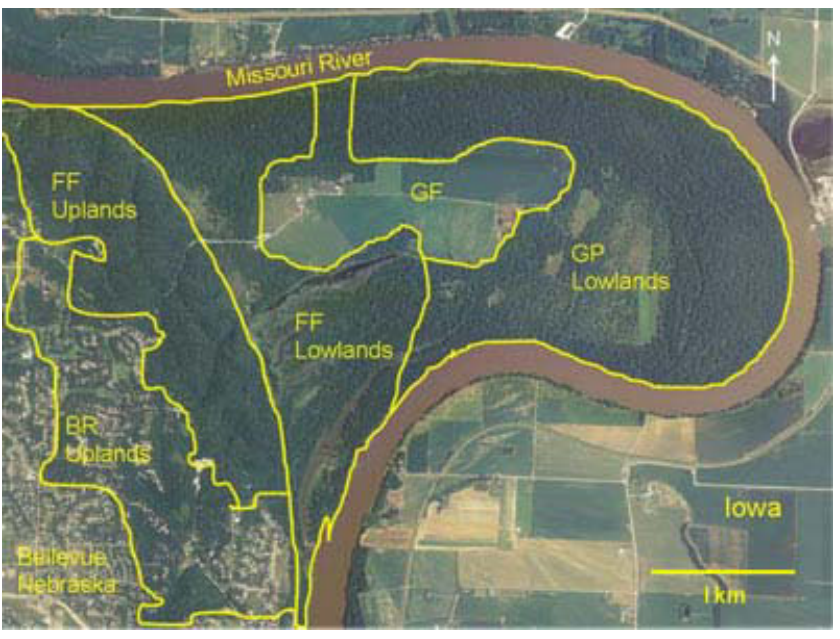

Figure 1. Study area consisted of Fontenelle Forest Nature Association (FF) uplands and lowlands, Gifford Point Wildlife Management Area (GP), Gifford Farm (GF), and Bellevue residential (BR) area near Omaha, Nebraska, USA, 1995-2010.

allowed in FF since its inception in 1921. Gifford Point was a 509-ha forested floodplain managed by the NGPC for wildlife and hunting. A 162-ha agricultural area known as Gifford Farm (GF) was located between GP and FF and incorporated into GP for this study. It was managed by the local Educational Services Unit (ESU) and served as a youth center for agricultural education. Corn, soybeans, and alfalfa were primary crops. The BR area collectively occupied about 400 ha of upland forest and consisted of several city parks, camps, residential subdivisions and developments, acreages, and a golf course. The residential area sloped westward into an urban business-industrial municipality of Bellevue that bounded the study area to the west. In 1965, housing developments started to replace previously rural areas consisting of orchards, pastures, and natural woodlands. As subdivisions grew, much of the natural landscape was preserved for aesthetic value. In addition, we included in the study Neale Woods (NW), a 224-ha wooded natural area and environmental center in northern Omaha with management programs similar to FF, only for including labor and deer harvested for estimating costs of managing controlled hunts. No biological data were collected from NW.

The study area was occupied by 550 species of vascular flora (Garabrandt 1988). Predominant plant communities included mature floodplain forest, forested river bluffs, upland suburban forest, and cultured turfgrass. The area also included floodplain agricultural fields, grassland savannas, and oxbow wetlands. Dominant trees species in the floodplain included cottonwood (Populus deltoides), silver maple (Acer saccharinum), and sycamore (Platanus occidentalis). Upland species included bur oak, shagbark hickory, black walnut (Juglans nigra), American elm (Ulmus americana), green ash (Fraxinus pennsylvanica), red elm (U. rubra), and hackberry. Predominant understory woody plants included ironwood, redbud (Cercis canadensis), red mulberry (Morus rubra), rough-leafed dogwood (Cornus drummondii), coralberry (Symphoricarpos orbiculatus), poison ivy (Toxicodendron radicans), and Virginia creeper (Parthenocissus quinquefolia). 
White-tailed deer were uncommon in the study area from 1900 to mid-1960s. Deer began to thrive and due to low mortality and availability of abundant suburban resources (i.e., irrigated turf grasses and landscape plants with longer growing seasons than native vegetation), the density of deer in the study area increased dramatically (Hygnstrom and VerCauteren 1999). In 1995, we estimated the density of deer in the study area at $27 \mathrm{deer} / \mathrm{km}^{2}$ (VerCauteren and Hygnstrom 2000).

\section{METHODS}

\section{Hunt Management}

The FF staff, in conjunction with the NGPC and BDTF, established population goals for white-tailed deer at 6 deer/ $\mathrm{km}^{2}$ in the FF uplands and FF lowlands, because of primary interests in protecting endemic plant species and communities. Annual controlled deer hunts began on FF during December 1996 to reduce densities of white-tailed deer. Hunts consisted of 9-day antlerless archery seasons in FF upland and coinciding 9-day antlerless muzzleloader seasons in FF lowland from 1996 to 2010. Four-day muzzleloader seasons were added in the lowlands and uplands in January 2002-2010. In addition, depredation permits were secured by FF staff from NGPC in 2004-2010. From 2001 to 2010, hunters with statewide buck permits were allowed to harvest antlered deer. A point system was developed in 2001 to enable holders of Nebraska statewide deer-hunting permits to earn and harvest an antlered male at FF. Hunters had to accumulate and "cash in" 3 points. Points were attained by the following model:

Years hunting deer at FF: 0.2 point/year up to 1 point. $>20 \mathrm{hr}$ hunting at FF: 0.5 point up to 0.5 point.

Harvested male fawn or spike male: 0.5 point.

Harvested adult female: 1 point.

Deer hunts were conducted in FF during mid-December and early January when public visitation at FF was relatively low. All of FF, except the Visitor Center, was closed to public access during hunts. Archers were allowed to hunt in FF uplands adjacent to BR area, but they had to be $>100 \mathrm{~m}$ from inhabited dwellings and roads and $>50 \mathrm{~m}$ from other archers. Muzzleloader hunters were allowed in FF lowlands away from inhabited dwellings and $>150 \mathrm{~m}$ from roads and other hunters, to minimize the disturbance that might be caused by the public observing hunters in the field or experiencing noise pollution associated with discharge of muzzleloaders, and the chance of stray bullets impacting any person or personal property in the BR area. Muzzleloaders were allowed in FF lowlands and uplands during hunts in January to increase harvest of deer adjacent to BR area. Each hunter was allowed to select a specific site in which he or she could establish their stand (veteran hunters at FF had preference) and could not change stand locations without notifying FF staff. All hunters were required to use elevated stands and safety harnesses if they were physically capable of doing so; hunters were not allowed to stalk or stillhunt. The only restriction imposed on stands was that no nails or screws could be imbedded in trees. Elevated stands had to be removed within 7 days of the last day of each hunt. Managers at FF reserved the right to remove any stands on their property. Archery hunters were required to wear an orange-colored hat or vest while walking to and from stands and muzzleloader hunters had to wear $>0.26 \mathrm{~m}^{2}$ of visible orange-colored clothing at all times during hunts. All hunters were required to be $>21$ years old and show proof of having completed a bow hunter or firearm safety course. Prospective hunters also had to pass proficiency tests; archers had to hit the vitals on a 3-dimensional deer target with 4 of 5 arrows from $20 \mathrm{~m}$ and muzzleloader hunters had to hit within a $15-\mathrm{cm}$-diameter circle with 4 of 5 shots at $50 \mathrm{~m}$.

Hunters at $\mathrm{FF}$ were required to participate in a hunt orientation 1 week before the hunt and pay a US $\$ 20$ hunt administration fee (all currency hereafter given in US dollars). The orientation addressed all site-specific rules and regulations, including dates of the hunt, daily registration, identification cards, legal hunting devices, hunt areas, marking trails and cutting vegetation, registration of harvested deer, veteran hunter preference, emergency procedures, and contact information. Hunters were encouraged to practice good hunter behavior, harvest antlerless deer (any deer with no antlers or antlers $<21.24 \mathrm{~cm}$ long), and spend up to $10 \mathrm{hr}$ hunting if a deer was not harvested. Hunters were informed that participation in future hunts would be dependent on these factors.

On opening weekends of the December hunts at FF, 2 registration stations were staffed and hunters had to enter the area between 0500 hours and 0630 hours or after 0930 hours to minimize the effect of late arrivals walking to their stands during prime hunting hours and disrupting the hunt of others. On other days of the hunts, hunters were required to register on their own at the registration stations. In all cases, hunters had to identify their hunt times and stand locations so FF staff would know who was in the woods and where and when. Hunters were required to carry a stateissued permit and FF hunter identification card on their person and display a vehicle pass in their vehicle. Two or more FF staff were on duty throughout the days during the December and January hunts and one or more remained in the evening until all hunters had checked out and were off the premises. Staff of FF assisted hunters in trailing wounded deer that traveled off FF hunt area. Any field dressing of harvested deer had to occur $>100 \mathrm{~m}$ from any trails, roads, or occupied dwellings. Carts and sleds were available to hunters and deer that were brought out of the woods had to be covered with a tarp to limit viewing by the public. Because parts of $\mathrm{FF}$ were remote and rugged, $\mathrm{FF}$ staff frequently assisted in retrieving deer with an all-terrain utility vehicle.

Hunts were administered by a hunt manager, who provided oversight to all aspects of the hunts. Volunteers and staff of FF assisted the hunt manager in registering hunters, marking hunt boundaries, providing security, and removing harvested deer. Sentries were deployed at access points to FF to limit public access during hunts. The FF hunt was included in the NGPC Big Game Hunting Guide that typically was distributed in late March. Interested hunters were directed to call 
FF for information about deer hunts by 1 July. Information about hunts was provided and an application and 2-page description of the hunt, area, prerequisites, and regulations were sent so that they could be returned by 31 July. Applications were reviewed in May-July. Shooting proficiency tests were conducted in August-September. Hunter orientation materials were sent to hunters in October. Hunt boundaries were marked, signage installed, and volunteers coordinated in November. Hunter orientations and hunts were conducted in December-January. Hunter evaluations, posthunt cleanup, and hunter pot-luck dinners were conducted in January.

The population goal for white-tailed deer in GP was established at $15 \mathrm{deer} / \mathrm{km}^{2}$ by NGPC to provide for maximum hunter recreation. Deer hunting on GP began in 1965 and consisted of annual 3-month archery seasons (19652010) and intermittent 9-day rifle (1974-1976) and muzzleloader seasons (1980, 1982-1984, 1992-1993, 1996-2001; Hygnstrom and VerCauteren 1999). Hunters in GP were allowed to harvest deer of either sex. Very limited deer hunting occurred in the BR area on rural private inholdings prior to 2004. In 2004, the City of Bellevue annexed these properties and initiated annual limited archery hunts, modeled after the archery hunts conducted in FF.

We recorded the amount of time spent by FF staff and volunteers for administration of controlled hunts in FF and NW and depredation hunts in FF during 2007-2009. We calculated personnel costs based on $\$ 23.07 / \mathrm{hr}$ plus $10 \%$ for the hunt manager, $\$ 10 / \mathrm{hr}$ for FF staff, $\$ 15 / \mathrm{hr}$ for sentries, and $\$ 10 / \mathrm{hr}$ for volunteers to get a reasonable estimate of costs required to implement the hunts. We also calculated costs for materials and services such as postage, printing, signs, phone calls, ammunition for depredation hunts, and insurance.

\section{Hunt Evaluation}

Registration of harvested deer was mandatory in Nebraska during the study period. All deer that were harvested by hunters in FF from 1996 to 2010 were required to be registered at the FF check station. All deer harvested at GP during 1973-2001 were registered at the GF check station. From 2002 to 2010, registration of hunters and deer harvested at GP was suspended. Harvested deer could have been registered at any NGPC check station across the state, but we assume all were registered at 1 of the 3 check stations proximate to GP (K. Hams, Nebraska Game and Parks Commission, personal communication). Data on number of deer harvested at GP were evaluated and provided by NGPC. Sex and age (fawn, ad) were determined for all deer at check stations. Deer taken at FF with rifles by FF staff and volunteers under NGPC depredation permits from 2004 to 2010 were sexed, and reported to NGPC. The number of deer harvested during depredation hunts was added to the number harvested in the previous year. We evaluated total harvest, number of hunters, sex ratios, and hunter success rates across years and used a Pearson's correlation coefficient to determine relationships between numbers of hunters and harvested deer across years.

\section{Deer Population Estimation}

We conducted helicopter counts of white-tailed deer in the study area within $24 \mathrm{hr}$ of $10-20-\mathrm{cm}$ snowfalls to maximize sightability of deer during January 1995, 1997, 1999, 2001, 2002, 2003, 2004, and 2006. Counts were limited to these years because of untimely lack of funding, snow cover, or helicopter availability. We flew east-west transects about $400 \mathrm{~m}$ apart at an altitude of about $100 \mathrm{~m}$ and speed of $<35 \mathrm{~km} / \mathrm{hr}$ to maximize sightability of deer and yet minimize disturbance that might cause deer to flee. We used an experienced pilot and designated observer and recorder during each of the counts, and followed the same procedures each year so that we could compare counts among years. Beringer et al. (1998) used a similar procedure in oakhickory forests and reported it to be an accurate and precise method of counting deer. Based on reports of the observers, we assumed that all deer in the study area were counted and that no repeat counts of individuals occurred. The study area was subdivided by GP lowland, FF lowland, FF upland, and $\mathrm{BR}$ area.

\section{Deer Home Ranges}

We conducted a 2-year telemetry-based study of white-tailed deer in the area (Hygnstrom and VerCauteren 1999) to determine seasonal movements, home ranges, habitat use, and survival of white-tailed deer in the study area and their response to hunting activity. We captured 98 deer during February 1995 to March 1996 with netted-cage traps (VerCauteren et al. 1997), rocket nets, and remote chemical immobilization. Fifty female white-tailed deer (22 ad, $>12$ months old; 28 juv, 8-12 months old) were equipped with very-high-frequency radiocollars (Advanced Telemetry Systems, Isanti, MN) and ear tags for individual recognition. We concentrated our telemetry efforts on female deer because 1) matriarchal family groups led by adult females make up the largest proportion of the population (Porter et al. 1991, Mathews and Porter 1993, Aycrigg and Porter 1997), and 2) knowledge of female survival is critical for predicting population changes (Porter et al. 1991, Mathews and Porter 1993, Aycrigg and Porter 1997, Hansen et al. 1997). We located radiomarked females $\leq 4$ times/wk from 17 February 1995 to 31 March 1997. We increased tracking intensity during crepuscular periods and at night to fully represent home ranges when deer were most active. For telemetrybased locations, we obtained 2-4 receiver bearings from mapped receiving sites. Bearing accuracy was $\pm 1.9^{\circ}$. The average time between bearings was $5 \mathrm{~min}$. We omitted all locations in which bearings were taken $>10$ min apart or error polygons exceeded 2.0 ha. About $50 \%$ of the telemetry locations were confirmed by visually observing individual deer. All methods were approved by the University of Nebraska-Lincoln Institutional Animal Care and Use Committee (No. 95-02-007). We used the Spatial Ecology Analysis System (J. R. Cary, University of Wisconsin-Madison, WI) to generate deer locations from telemetry data. A land cover-map and deer location overlays were developed using the Map and Image Processing System (MicroImages, Lincoln, NE). We used a harmonic mean 
method (Dixon and Chapman 1980) to estimate annual home ranges from deer locations. We felt this method was more appropriate than kernel-based procedures because with sample sizes $<30$, kernel estimators tend to overestimate home range size while other methods underestimate home range size (Seaman et al. 1999). The mean number of locations/deer/year was $114(\mathrm{SE}=10$, range $=8-247)$. We used the $95 \%$ isopleth to delineate the boundary of each annual home range (White and Garrott 1990).

\section{Response of Vegetation}

Limited resources prevented us from developing a comprehensive study on plant communities across the 15 -year period. We did, however, assemble the results of 6 independent studies to provide information on the response of vegetation to reductions in the local deer population. The effects of deer browsing on vegetation and nesting and foraging birds were evaluated in eastern Nebraska (Gubanyi et al. 2008); 2 of their study areas included FF and GP. In March 1996, we erected 4 square $33-\mathrm{m} \times 33-\mathrm{m}$ deer exclosures surrounded by 2.5 -m-tall woven-wire fencing; 2 were randomly located in GP lowland, 1 in FF lowland, and 1 in FF upland. Recovery of vegetation inside versus outside exclosures was compared by Rupiper (2003). Sixteen $20-\mathrm{m} \times 30-\mathrm{m}$ vegetation plots were randomly located throughout $\mathrm{FF}$ in 1973. Woody-stem counts were conducted in plots in 1973 and 1994 and results were compared (G. Garabrandt, unpublished data). We conducted browse utilization surveys of current annual growth (Jensen and Scotter 1977) in FF and GP in October 1994 to estimate the availability and use of shrubs and saplings within reach of deer. Two sampling areas along the border of FF upland and BR area were established in 2004 to document the distribution of garlic mustard (Alliaria petiolata). Twenty $0.5-\mathrm{m}^{2}$ plots were established in each sampling area and vegetation was regularly evaluated from 2004 to 2010.

Coralberry, rough-leaved dogwood, newly emerged root shoots of American linden, wood nettle (Laportea canadensis), and jewelweed (Impatiens capensis and I. pallida) appear to be highly preferred by deer at FF because the woody species are extensively browsed throughout the year and the annuals are the first plants to be browsed by deer in spring (G. Garabrandt, unpublished data). Therefore, we used them as indicators of habitat recovery from overbrowsing by deer.

\section{RESULTS}

\section{Hunt Management}

Number of hunters/year at FF increased from a low of 47 during 1996 to a high of 132 in 2008 (Fig. 2). Number of archery hunters at FF started at 34 in 1996, increased to a high of 51 in 1998 and was relatively static across the years until 2009. Number of muzzleloader hunters at FF increased steadily from a low of 13 in 1996 and leveled off around 80 from 2006 to 2008. Total annual number of hunters at GP ranged from a low of 93 in 1973 to a high of 476 in 1992 (Fig. 3). More typical lows of $<100$ were observed at GP from 1973 to 1980. Archers hunted in GP from 1973 to 2009

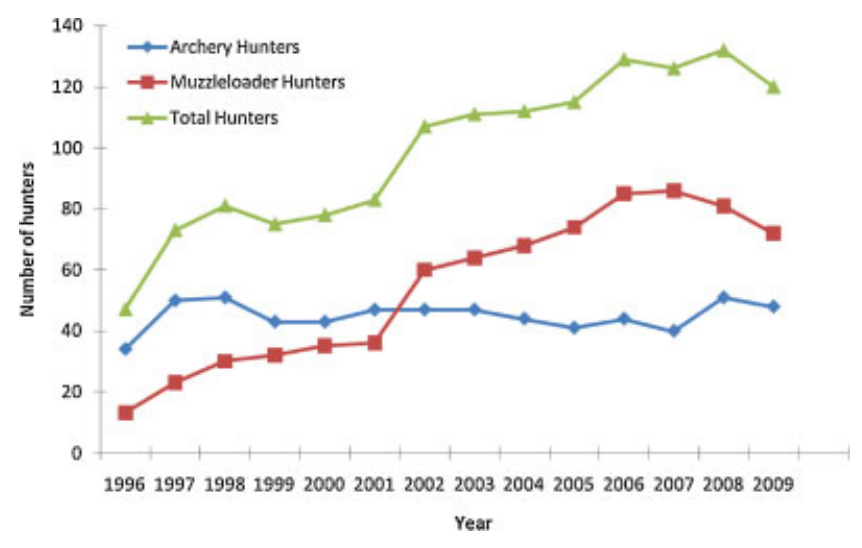

Figure 2. Number of deer hunters at Fontenelle Forest near Omaha, Nebraska, USA during controlled hunts using archery and muzzleloader permits, 1996-2009.

and made up the majority of total annual number of hunters across the years. A record 141 muzzleloader hunters participated at GP in 1992. Hunting with rifles was allowed only 3 years, 1974-1976.

Behavior of hunters at FF was admirable, with no complaints from the public received by FF staff or agencies in the surrounding area. No hunter incidents or accidents were reported for FF. In 1999, a GP hunter accidentally was shot by another GP hunter swinging on game. After the incident the ESU stopped managing hunts due to concerns over liability. Reduced access to hunters led to reduced harvests in the northern area of the GP lowlands. In 2004 FF and ESU negotiated a trade of property that allowed NGPC to construct a road that enabled access to hunters throughout the GP lowland.

Labor required to administer controlled hunts in $\mathrm{FF}$ and NW during 2007-2008 included hunt manager (214 hr), FF staff (312 hr), sentries (157.5 hr), and volunteers (132.5 hr) for a total labor cost of $\$ 12,238$. Costs for materials (postage [\$97], copying [\$38], maps [\$20]) and event insurance $(\$ 2,500)$ were partially offset by income from hunter administration fees (collected from 85 hunters $\times \$ 20=\$ 1,700$ ). Total adjusted costs $(\$ 13,193)$ divided by number of deer

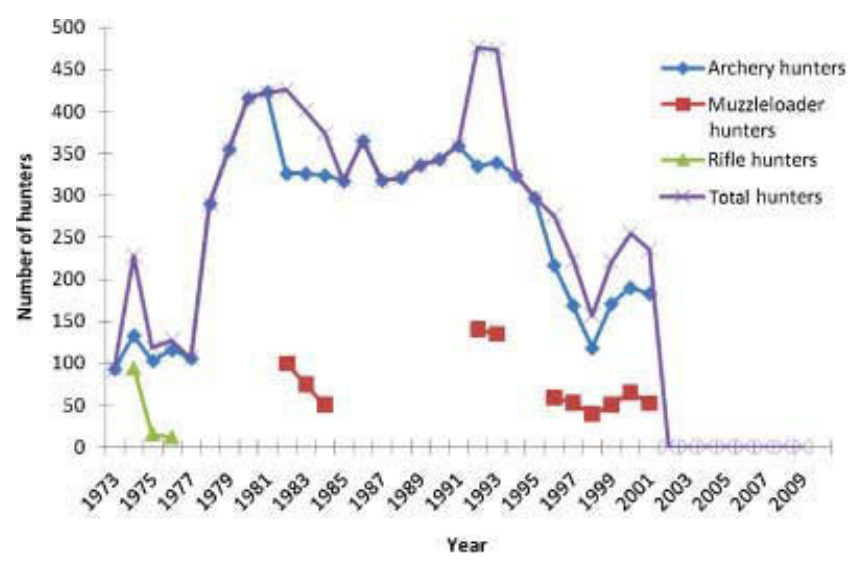

Figure 3. Number of deer hunters at Gifford Point Wildlife Management Area, Nebraska, USA, during regular hunting seasons using archery, muzzleloader, and rifle permits, 1996-2009. The number of hunters drops to 0 after 2001 because on-site registration of hunters was suspended. 
harvested in controlled hunts in FF $(n=91)$ and NW $(n=21)$ during 2007-2008 resulted in a cost of $\$ 120$ / deer (at 2010 prices; US Department of Labor 2011). Labor required to administer depredation hunts in FF during January-March 2008 included hunt manager (45 hr), FF staff $(75.5 \mathrm{hr})$, and volunteers $(46 \mathrm{hr})$ for a total labor cost of $\$ 2,427$. Cost of ammunition was $\$ 70$. Total adjusted costs $(\$ 2,497)$ divided by number of deer harvested in depredation hunts in FF $(n=36)$ resulted in a cost of $\$ 70 /$ deer (at 2010 prices).

\section{Hunt Evaluation}

Total annual harvest of white-tailed deer at FF increased from a low of 28 during the first hunt in 1996 to a high of 140 in 2006 and leveled off from 2007 to 2009 (Fig. 4). Harvest by archers in FF uplands started at 18 deer in 1996, increased to a high of 39 in 2001 and decreased steadily to a low of 11 in 2009. Harvest by muzzleloaders in FF lowlands increased from a low of 10 deer in 1996 and fluctuated around 75 from 2003 to 2008.

Total annual harvest of white-tailed deer corresponded closely with the total number of hunters/year $(r=0.925)$ and number of muzzleloader hunters/year $(r=0.894)$. Staff and volunteers of FF harvested 18-70 antlerless deer under depredation permits from 2004 to 2010. The ratio of does:bucks in total annual harvest was 4.8:1 in 1996. It dropped to 1.1:1 in 2001, the first year that hunters were allowed to harvest antlered deer. In subsequent years, the ratio typically ranged from 1.5 to 3.0 females: 1 male.

Success rates of archery hunters ranged from $22.9 \%$ in 2009 to $83.0 \%$ in 2001 and typically were $>40 \%$. Success rates of muzzleloader hunters ranged from $57 \%$ in 1998 to $134 \%$ in 2000 and typically were $>80 \%$. Overall mean success rates of archery and muzzleloader hunters in FF were 52\% and 93\% from 1996 to 2009, respectively.

Total annual harvest of white-tailed deer at GP varied greatly across the years, with an exceptionally low reported harvest of 8 in 2009 (questionable data because no check station was staffed on-site after 2001), and more typical lows of around 45 in 1973, 1997, 1998, and 2008 (Fig. 5). A high of 193 deer were harvested in 1992, with other relatively high harvests around 150 in 1983 and 1990. Total number of hunters at GP decreased steadily across the years and total

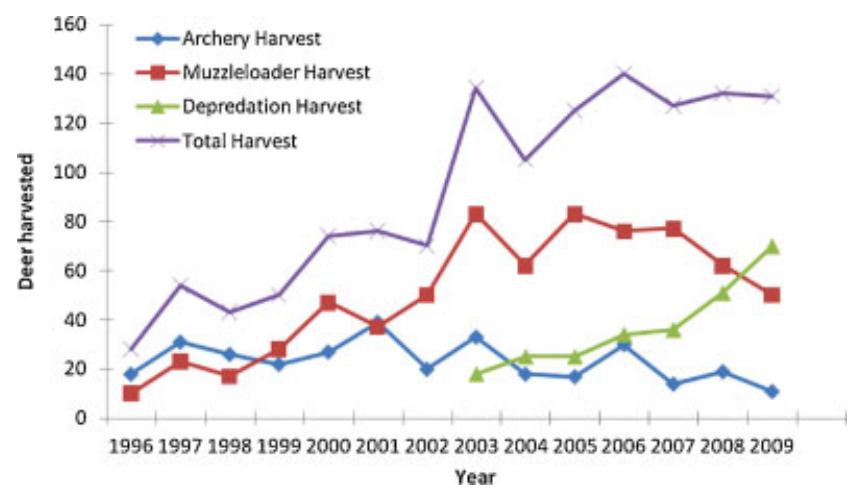

Figure 4. Number of deer harvested at Fontenelle Forest, Nebraska, USA, during controlled hunts using archery, muzzleloader, and depredation permits, 1996-2009.

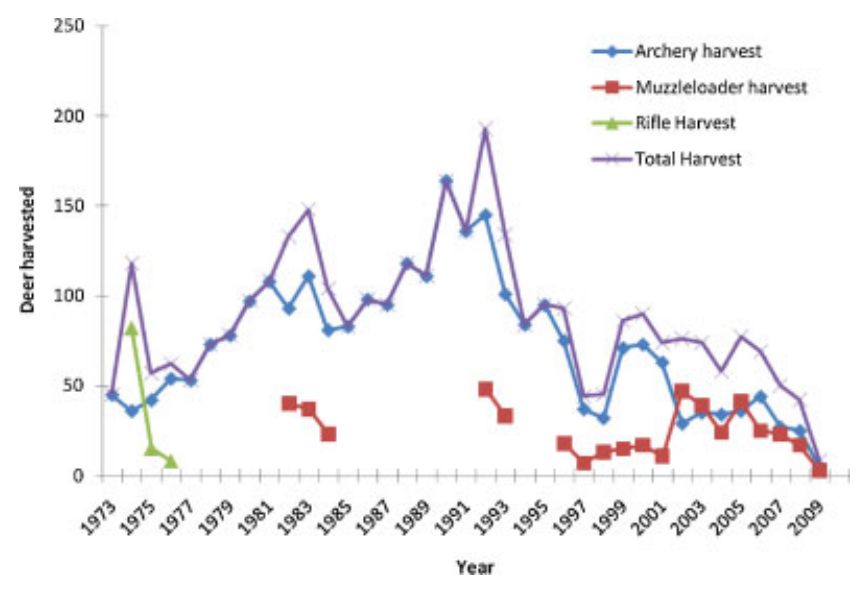

Figure 5. Number of deer harvested at Gifford Point Wildlife Management Area, Nebraska, USA, during regular hunting seasons using archery, muzzleloader, and rifle permits, 1973-2009. The number of deer harvested after 2001 is questionable because on-site deer registration was suspended and numbers were collected from 3 adjacent regional check stations.

harvest of white-tailed deer corresponded $(r=0.779)$. The ratio of adult females:adult males in the either-sex harvest varied from 0.3:1 in 2001 to 1.4:1 during 1990. The sex ratio typically ranged from 0.5 to $1: 1$ in other years. Most deer harvested in GP across all years were taken by archers. Archers harvested 32-164 deer annually and success rates ranged from $22 \%$ to $50 \%$ during $1973-2001$, when reliable harvest data and numbers of hunters were recorded on site. Hunting with muzzleloaders was allowed sporadically and during about half of the years in GP. Total annual harvest by muzzleloader hunters never exceeded 50 deer and success rates were $<50 \%$ in all years. Overall mean success rates of archery, muzzleloader, and rifle hunters in GP from 1973 to 2001 were $33 \%, 30 \%$, and $82 \%$, respectively.

\section{Deer Population Estimation}

The helicopter survey in January 1995 revealed 495 deer $\left(27 \mathrm{deer} / \mathrm{km}^{2}\right)$ in the study area (Fig. 6; VerCauteren and Hygnstrom 2000). Subsequent helicopter counts showed a slow, but variable decline in number of deer in the study area, with a low of 253 deer $\left(15 \mathrm{deer} / \mathrm{km}^{2}\right)$ counted in 2006.

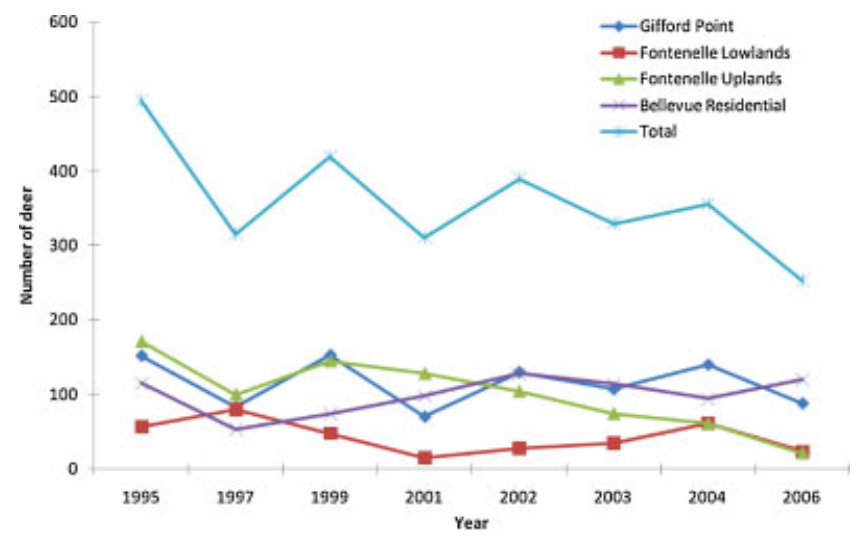

Figure 6. Helicopter counts of white-tailed deer in a $16.5-\mathrm{km}^{2}$ developed environment near Omaha and Bellevue, Nebraska, USA, 1995-2006. Study area consisted of Gifford Point Wildlife Management Area $\left(5.2 \mathrm{~km}^{2}\right)$, Fontenelle Forest Lowland $\left(3.5 \mathrm{~km}^{2}\right)$, Fontenelle Forest Upland $\left(3.8 \mathrm{~km}^{2}\right)$, and Bellevue Residential area $\left(4.0 \mathrm{~km}^{2}\right)$. 
Number of deer in FF uplands declined slowly but steadily, while numbers in BR area increased slowly from 1995 to 2006. Number of deer in BR area grew to be among the highest in the study area. Number of deer in GP lowlands fluctuated and exhibited no steady increases or declines across the 10-year period. Number of deer in FF lowlands was lowest of all in 1995 and remained the lowest of all areas across the 10-year period.

\section{Deer Home Ranges}

Mean size of annual home ranges of 50 radiocollared female deer was 275 ha (range $=18-4,265$ ha, $\mathrm{SE}=88$ ha; Hygnstrom et al. 2011). Forty-one of the 50 deer (82\%) were residents that displayed relatively small home ranges $(\bar{x}=115 \mathrm{ha}, \quad \mathrm{SE}=13 \mathrm{ha})$ and seasonal movements $(<1,000 \mathrm{~m})$, and exhibited large overlaps $(\bar{x}=66 \%$, range $=10-100 \%)$ between winter and nonwinter seasons. Seven deer dispersed and had large seasonal shifts in home range centers $(>1,000 \mathrm{~m})$, but they settled in areas ( 3 in NE, 4 in IA) that were similar in habitat type to the areas they left. Two others were migrants and had large seasonal shifts in home range centers $(>1,000 \mathrm{~m})$, but returned to areas previously occupied. Forty-four of the deer resided annually in the GP lowlands $(n=14), \mathrm{FF}$ lowlands $(n=11)$, and FF uplands-BR area $(n=19)$. Deer in the latter area frequently were observed in backyards, at deer feeders, and on city streets. Deer response to hunter activity was highly variable. The effect of archery hunting on size of home ranges was minimal $(+11 \%)$, whereas the effect of muzzleloader hunting was considerable in the short term $(+88 \%$; Hygnstrom et al. 2011).

\section{Response of Vegetation}

Associated studies confirmed heavy deer browsing on stems of all woody species in FF and GP (Gubanyi et al. 2008). Plot sampling revealed a $56 \%$ decline in the woody sapling layer of stems 1-3 m tall from 1973 to 1994 (G. Garabrandt, unpublished data). An apparent increase in the seedling layer (stems $<1 \mathrm{~m}$ tall) consisted of older sapling-aged trees that had been chronically browsed to stubble. Growth ring counts confirmed that $46-\mathrm{cm}$-tall hackberry and green ash stems were 15 years old. Browse utilization surveys in 1994 revealed that $>60 \%$ of the available twigs in all transects were browsed, thereby rendering the conclusion of heavy browsing pressure (Hygnstrom and VerCauteren 1999). Sampling plots along the border of FF upland and BR area in autumn 2010 revealed that native woody species in unprotected plots were $\leq 20-30 \mathrm{~cm}$ tall. No woody plants outside an exclosure in FF were $>30 \mathrm{~cm}$ tall and all were browsed, yet $23-\mathrm{m}$ hackberry trees, $13-\mathrm{m}$ green ash, and $21.3-\mathrm{m}$ red oaks (Quercus rubra) occurred inside the exclosure.

\section{DISCUSSION}

\section{Hunt Management}

The number of hunting permits issued annually at FF was based on established population goals and interest in maximizing safety, maintaining reasonable hunter densities, and conducting a low-profile hunt. The number of permits available and total number of deer hunters at FF increased steadily from 1996 to 2008. Fontenelle Forest currently is in NGPC Deer Management Area 21, in which Season Choice Permits allow hunters to shoot 2 antlerless deer on a permit and hunters may purchase an unlimited number of permits. Hunter satisfaction and success rates were high, which translated into high retention and recruitment of hunters at FF. Several muzzleloader hunters who participated in regular FF deer-hunting seasons also participated in late-season hunts that were implemented in January 2002-2010. The point system that was implemented in 2001, largely to reward veteran FF hunters, was not abused. Between 1996 and 2000, the harvest consisted of adult females (71\%) and immature males (29\%). The number of females killed between 2001 and 2009 remained high at $62 \%$ and immature males was 29\%. Even though most veteran hunters accumulated enough points by shooting antlerless deer, only 72 antlered males (7\% of total harvest) were killed during all hunts.

During the first year of the hunt, $>300$ applications were mailed out and predictions were made that hunters would be 'beating down the door' to get in because FF had been off limits to hunting for a long time. Instead, only 52 applications were returned. We suspect that many were turned off by the antlerless-only requirement, hunt prerequisites, controversy generated by the media, and false rumors that FF deer were malnourished and small. Each April, hunters who participated in the previous season were mailed a hunt application and letter briefly listing the dates and details about the upcoming hunt. The veteran hunters were asked to return applications by 15 June. New hunters were recruited based on references of veteran hunters. Prospective new hunters were interviewed by phone. New hunters were encouraged to team up with veteran hunters for guidance.

Due to the proximity of the residential areas of Bellevue and Omaha, Nebraska, the BDTF perceived that it was of the utmost importance to manage a highly controlled hunter-access program to minimize likelihood of any adverse hunter behavior or safety incidents. The extensive rules and regulations specific to FF hunts were developed by the FF staff in consultation with NGPC staff and hunters using the FF area. Since 1996, when hunting was initiated in FF, no complaints of hunter behavior have been reported to FF staff and no accidents, incidents, or injuries have occurred to hunters or bystanders. Hunter density was relatively high during hunts, but this was addressed during the hunter orientation, so expectations of hunters would not be unrealistic. The requirements and recommendations of controlled hunts at FF likely contributed to safety and success of the hunts.

A conservation ethic and culture of management developed among many FF hunters and they willingly harvested antlerless deer in FF. The prehunt orientation, posthunt potluck dinner, and personal relationships among hunters and FF staff helped retain hunter interest and participation. The program that enabled hunters to earn the opportunity to harvest antlered deer has facilitated the retention of hunters at FF. Many hunters also volunteer their time serving on the FF Land and Trails Stewardship Committee. 
The closure of FF and all its trails was published in the FF member's newsletter, but keeping people out during hunts was a significant challenge. The main entrance to trails was at the Visitor Center, where it was easy to close trails with signage. However, 2 secondary trailheads were in more remote locations, so it was necessary to have 'sentries' on duty from 0800 hours to 1700 hours during days of the hunt. With permission from the county sheriff and roads department, FF blocked a county road and sentries allowed entry only to FF and GP hunters and those who had business at GF. All would-be trail hikers were turned away and sentries were able to communicate problems to FF staff via 2-way radio. Sentry duty was divided into $24.5-\mathrm{hr}$ shifts. Thirty-six shifts were required during the 9-day hunt in December and 16 shifts were required during the 2 weekend hunts in January. Hunt sentries were drawn from a pool of FF education and administration staff and a large corps of FF volunteers.

Efforts were made to educate the public about management of overabundant deer and deer damage in the study area, including public hearings; deer damage workshops; newspaper, newsletter, and research articles; and Extension publications (e.g., Hygnstrom and VerCauteren 1995, DeNicola et al. 2000, Hygnstrom et al. 2005). Considerable local media coverage addressed the first hunt of deer in FF in 1996, including articles in local newspapers and segments on 2 local television-station news broadcasts 2 days before the December hunt. Public protests associated with the hunts, however, were very limited. Twelve protesters were at FF on the morning of the hunt and were provided an area in the parking lot outside the FF Visitor Center in which they could protest. All were civil, with exception of 1 individual, who repeatedly tried to disrupt traffic on a local street. Local police controlled the individual's behavior and protesters left after $2 \mathrm{hr}$. In autumn of 1998, an unknown number of individuals demonstrated civil disobedience relative to the hunt and vandalized FF property by spreading nails across the FF parking lot and adjacent street the night before the start of the December hunt. Protests and other forms of objection or disruption of the hunts were minimal to nonexistent thereafter.

An insurance rider for the hunts was secured in 2005-2008 for $\$ 1,000-\$ 2,500 /$ year, but the annual policies were dropped after 2008 when it was discovered that they provided only third-party coverage and that the existing policy for FF provided $\$ 5,000,000$ coverage/year for all events on the property, including controlled hunts. In addition, all hunters at FF had to sign a release form each year that identified their voluntary participation in hunts, and that they willingly assumed all risks and responsibility of injury or damage; would abide by all laws, rules, and regulations; and release and hold harmless FNA.

We calculated a total cost of $\$ 120 /$ deer harvested during controlled hunts in FF and NW and $\$ 70 /$ deer during depredation hunts at FF in 2007-2008. These costs are comparable (at 2010 prices; US Department of Labor 2011) to sharpshooting (Ishmael and Rongstad 1984, DeNicola et al. 2000), less than trap-and-shoot (\$153/deer; Ishmael and Rongstad 1984), and considerably less than trapand-transport (\$900/deer and \$637/deer; O'Bryan and McCullough 1985, Ishmael et al. 1995, respectively) and trap-and-sterilize ( $\$ 1,007 /$ deer; Mathews et al. 2005). Also, none of the latter methods generally are documented or recommended to reduce densities of deer.

\section{Hunt Evaluation}

Total annual harvest of white-tailed deer in $\mathrm{FF}$ increased nearly 5-fold from the first year of hunting in 1996 to 2006 (Fig. 4). Total harvest declined after 2006, likely due to the declining number of deer available in the FF uplands and lowlands, reduced participation by muzzleloader hunters, and severe winter weather during hunts in 2009-2010. Depredation permits enabled additional harvest of deer after the controlled hunts in FF uplands, especially adjacent to BR area, where controlled harvest initially was not sufficient to reduce densities of deer to population goals. Depredation permits especially were important in 2009-2010, when blizzards during controlled hunts in December and January significantly reduced hunter participation and deer harvest. Volunteers and FF staff harvested 70 antlerless deer in the FF uplands in January 2010, which compensated for the number of deer that were not harvested during controlled hunts. The sex ratio of harvest in FF has been biased toward adult females during all years, except for 2001, the first year in which harvest of antlered males was allowed. Most hunters in FF harvested antlerless deer and many developed an ethic of harvesting only adult females to help the cause of reducing recruitment and density of deer at FF. The sex ratio of harvests in FF were much more skewed toward females than in GP, where hunters were more motivated toward harvesting males and there were lower hunter densities and a much less regulated hunt experience. To put things in perspective, statewide harvest of white-tailed deer in Nebraska has increased steadily over the past 2 decades, with record numbers of permits sold (141,573), white-tailed deer harvested $(77,028)$, and antlerless deer harvested $(39,198)$ in 2010 (Nebraska Game and Parks Commission 2011).

Total annual number of hunters at FF increased steadily across the years and total annual harvest was closely correlated, with the exception of 2009 (Fig. 2). Total annual harvest of white-tailed deer corresponded closely with the total number of hunters/year $(P=0.925)$ and number of muzzleloader hunters/year $(P=0.894)$. Overall mean success rates of archery and muzzleloader hunters $(52 \%$ and $93 \%$, respectively) were relatively high compared to previous studies (Gladfelter et al. 1983, McPhillips et al. 1985, Boulanger et al. 2006) and influenced by the fact that all hunters were allowed to harvest 2 deer with a single permit and some hunters purchased multiple permits.

Total annual harvest of white-tailed deer in GP was highly variable across the 29-year period that records were maintained (Fig. 3). Harvests peaked at 193 deer in 1992, but declined precipitously shortly thereafter, likely due to declining hunter participation. The typical sex ratios of the eithersex harvest (0.5-1 ad F:1 ad M) was highly skewed toward 
adult males, compared to harvests in FF and revealed a high level of selectivity for bucks occurring in GP. The area was an important resource for urban and suburban bowhunters, as 300-400 archers/year registered during 1978-1995 and success rates typically exceeded $30 \%$. Overall mean success rate of archery hunters (33\%) was respectable, and muzzleloader hunters (32\%) were relatively low at GP compared to FF but higher than a previous study (Boulanger et al. 2006). Success rates likely were influenced by the either-sex permits, 3-month-long season, and resultant selectivity by hunters for antlered males.

\section{Deer Population Estimation}

Densities of white-tailed deer in the study area declined since the initiation of hunting seasons in 1996 (Fig. 6), but harvest and posthunt deer remaining on the landscape were not evenly distributed across the landscape. Densities were near overwinter goals in FF lowlands, FF uplands, and GP lowlands $\left(7\right.$ deer $/ \mathrm{km}^{2}, 5$ deer $/ \mathrm{km}^{2}$, and 13 deer $/ \mathrm{km}^{2}$, respectively) in 2006. The elevated density of deer in BR area in 2006 (30 deer $\left./ \mathrm{km}^{2}\right)$ likely was due to several factors, including limited harvest that occurred in the area. The city of Bellevue initiated an In-city Archery Deer Hunt Program in 2004, which enabled landowners or their designees to hunt on property within the city limits if they met necessary criteria (hunter education certification, shooting proficiency, stand placement $>100 \mathrm{~m}$ from residences, and elevated stands; based on FF requirements). Unfortunately, few deer were reported and no records were maintained by the city of Bellevue. In addition, supplemental feeding of deer in the BR area was common in the early 1990s. The BDTF met in 2002 and discussed a ban on deer feeding with officials of the city of Bellevue, but no ban was implemented. An educational program that encouraged against feeding deer likely decreased participation of residents in this activity. At least 3 individuals in the BR area continued to feed deer through 2010 and occasionally had 20-30 deer in the vicinity of their property (G. Garabrandt, unpublished data). Feeding of deer likely reduces hunter success in FF because it holds deer in BR areas where hunting currently is not allowed and that are adjacent to FF.

\section{Deer Home Ranges}

Eighty-two percent of radiomarked female white-tailed deer in our study were residents of FF and GP (Hygnstrom et al. 2011). Mean size of home ranges of these resident deer $(\bar{x}=115 \mathrm{ha})$ were larger than those in a Midwest urban park (73-111 ha in Minnesota, Grund 1998) and smaller than those in Midwest agricultural landscapes: 170 ha in Nebraska (VerCauteren 1993) and 162 ha in Iowa (Gladfelter 1978). Cornicelli (1992) and Grund (1998) reported daily activities of urban and rural deer were similar, but urban deer had smaller home ranges. Emigration rates were low, even at high densities of deer. Therefore, mortality due to hunting likely will have to increase to reduce densities of deer and maintain deer at population goals. Deer used upland forest and adjacent residential areas year-round. We detected no migratory patterns in deer using the FF upland$\mathrm{BR}$ area; therefore, deer that used the upland areas were not susceptible to public hunting that occurred on GF or GP lowland areas. In general, effects of hunting on deer home ranges were minor, but highly variable. Most deer maintained high fidelity to their home ranges, even when exposed to muzzleloader or archery hunting activities. Deer in GP lowlands experienced little interaction with humans until autumn hunting seasons and contact with hunters likely stimulated significant avoidance response. In contrast, deer in FF were exposed to high levels of human activity (e.g., hikers, boardwalk visitors, and school groups) throughout the year and often were fed in the BR area. As a result, many deer in FF uplands and BR area were acclimated to humans. The population of deer exceeded goals and no consistent dispersal or migration patterns were observed; therefore, we suggest that controlled hunting seasons continue in $\mathrm{FF}$ and $\mathrm{GP}$ and in open-space areas of BR area where conditions are conducive to hunting.

\section{Vegetation Response}

We recognize that studies on vegetation at $\mathrm{FF}$ and $\mathrm{GP}$ were not extensive or well coordinated, but as a combined set, they tell a story of significant impacts by deer at high densities and concomitant recovery when local densities of deer declined. Data from 20-year-old vegetation sampling plots indicated that deer use of shrubs and saplings were high prior to 1995. Regeneration of overstory species such as bur oak, shagbark hickory, and American linden was nonexistent. Over 20 herbaceous species disappeared from FF since deer started inhabiting the area in the early 1960s. Deer-resistant snakeroot, stinging nettles (Urtica dioica), barberry, and tree of heaven invaded areas while native woodland forbs disappeared. Deer exclosures and browse utilization surveys in 1995 confirmed that excessive levels of browse damage by deer had occurred throughout FF and GP. Plot sampling in 1994 revealed that coralberry had been heavily browsed and were $<5 \mathrm{~cm}$ tall. Rough-leaved dogwood, which is invasive in some settings and spreads by trunk and root suckers, was limited to older trunks with no spreading.

Habitat within the northwestern FF upland and southeastern FF lowland (Fig. 1) has shown signs of recovery since 2000, including a resurgence of bur oak, hackberry, and linden sprouts since the decline in deer density. Other areas within FF lowland and lower elevation FF upland have shown signs of recovery since 2005. Coralberry can now be found growing to full height in the northern FF upland and southern FF lowland, where densities of deer are lowest. Rough-leaved dogwood is spreading vigorously in southern FF lowland and many shoots of American linden are growing free of deer browsing in northern FF upland. Wood nettle and jewelweed were nearly nonexistent throughout $\mathrm{FF}$ in the 1990s, but now they are abundant in the northern FF upland and southern floodplain of FF (G. Garabrandt, personal communication).

Areas in which vegetation has shown no sign of recovery from high levels of deer browsing include BR area and adjacent parts of FF upland, where densities of white-tailed deer remain high. Construction of homes and streets in BR area in the 1960s to present occurred on ridges and 
less sloping terrain, leaving deep ravines and steep wooded slopes in natural cover. Deer in these areas have adequate natural habitat, an extended growing season of ornamental plants and grasses, and access to several backyard feeding stations. Deer harvest in BR area is very limited and harvest in the adjacent FF upland may be the most important mortality factor that keeps densities of deer in BR area from growing higher than present levels.

\section{MANAGEMENT IMPLICATIONS}

Fifteen years of highly regulated deer hunting in FF and surrounding areas has led to reduced densities of deer and associated impacts to native plant communities in areas where harvest rates have been high. Unfortunately, densities of deer and associated overbrowsing have continued to increase in adjacent residential areas where hunter access has been limited. Fifteen years of experience in managing these hunts has rendered some common themes that we discussed earlier and highlight here. We believe these themes are essential for maintaining an effective, long-term, cooperative management program for reducing densities of white-tailed deer to tolerable levels in developed landscapes.

Collaboration - and engagement of primary stakeholders, agency personnel, and municipal officials through the BDTF led to cooperative efforts in identifying issues, garnering resources, and implementing programs. In addition, collaboration among hunters, volunteers, and FF staff led to successful hunts that enabled the reduction of deer densities and associated damage.

Communication - initially among members of the BDTF and then with the local public; FF members, press, volunteers, and hunters communicated effectively to facilitate a relatively incident-free management program for a 15 -year period.

Leadership - was critical in all aspects of the FF experience and our co-author Gary Garabrandt deserves all of the credit. $\mathrm{He}$ is a paid employee of FF and management of the landscape there was his responsibility. He formed the BDTF, fostered collaborations, facilitated communication, managed all hunts, and ultimately became a consultant to managers of other developed areas across the nation that were challenged with overabundant white-tailed deer.

Research-based management-became a standard for the BDTF so they could weather public scrutiny that was anticipated. Research included a review of all deer management options, which was a contributing factor to the development of a nationally recognized guidebook (DeNicola et al. 2000). In addition, research was conducted to document impacts of overabundant deer, deer densities, deer space use and response to hunting (Hygnstrom et al. 2011), results of hunts, and impacts of deer population reductions, as well as support establishment of population and harvest goals.

Adaptive management-was possible because of the research and annual review of results by G. Garabrandt and the BDTF. Fontenelle Forest implemented 6 major changes in the deer harvest management program during 15 years, which resulted in continuously increasing harvest of antlerless and antlered deer, especially in areas adjacent to the
$\mathrm{BR}$ area in which limited harvest occurred. As of winter 2006, white-tailed deer were at population goals in FF and GP.

Persistence-and patience. It took 10 years to reach population goals through controlled hunting at FF and the plan includes continued hunting to keep up with annual recruitment of white-tailed deer in FF and immigration from surrounding areas.

Resources-Of course, the above themes come with a cost. We documented costs for the hunts, but they are only a part of total costs in human capital and investments by associated agencies, organizations, volunteers, and other entities. Hunters and the willing commitment they made must never be overlooked. They paid to participate and supported conservation programs that were needed to restore health and environmental services of an area that is revered by all.

\section{ACKNOWLEDGMENTS}

We thank M. Dietz, B. Ekstein, J. Ekstein, C. Kearns, and several volunteers and hunters at $\mathrm{FF}$ who assisted with fieldwork and hunts. K. Finch, R. Gleason, K. Hams, and K. Lunstra provided access to documents, logistic support, and study area. Funding for the project was provided by Fontenelle Nature Association, Gifford Foundation, NGPC, Papio-Missouri Natural Resources District, Sarpy County, and University of Nebraska-Lincoln. D. Walter, S. Vantassel, and 2 anonymous reviewers provided many useful suggestions to the paper. G. Garabrandt provided most of the data and content for this paper. He has been instrumental in developing a deer harvest management program for $\mathrm{FF}$ and readily shared information to land managers across North America for over a decade. For more detailed information on managing urban deer hunts, contact $\mathrm{G}$. Garabrandt.

\section{LITERATURE CITED}

Aycrigg, J. L., and W. F. Porter. 1997. Sociospatial dynamics of white-tailed deer in the central Adirondack Mountains, New York. Journal of Mammalogy 78:468-482.

Bashore, T. L., W. M. Tzilkowski, and E. D. Bellis. 1985. Analysis of deervehicle collision sites in Pennsylvania. Journal of Wildlife Management 49:769-774.

Beringer, J., L. P. Hansen, and O. Sexton. 1998. Detection rates of whitetailed deer with a helicopter over snow. Wildlife Society Bulletin 26: 24-28.

Boulanger, J. R., D. E. Hubbard, J. A. Jenks, and L. M. Gigliotti. 2006. A typology of South Dakota muzzleloader deer hunters. Wildlife Society Bulletin 34:691-697.

Connelly, N. A., D. J. Decker, and S. Wear. 1987. Public tolerance of deer in a suburban environment: implications for management and control. Proceedings of the Eastern Wildlife Damage Control Conference 3:207-218.

Cornicelli, L. 1992. White-tailed deer use of a suburban area in southern Illinois. Thesis, Southern Illinois University, Carbondale, USA.

DeNicola, A. J., K. C. VerCauteren, P. D. Curtis, and S. E. Hygnstrom. 2000. Managing white-tailed deer in suburban environments - a technical guide. Cornell Cooperative Extension, Ithaca, New York, USA.

Diamond, J. 1992. Must we shoot deer to save nature? Natural History 8: 2-8.

Dixon, K. R., and J. A. Chapman. 1980. Harmonic mean measure of animal activity areas. Ecology 61:1040-1044. 
Etter, D. R., K. M. Hollis, D. R. Ludwig, J. E. Chelsvig, and C. L. Anchor. 2002. Survival and movements of white-tailed deer in suburban Chicago, Illinois. Journal of Wildlife Management 66:500510.

Garabrandt, M. M. 1988. An annotated list of vascular plants of Fontenelle Forest and Neale Woods in eastern Nebraska. Transactions of the Nebraska Academy of Sciences XVI:31-49.

Ginsberg, H. J., and E. Zhioua. 1999. Influence of deer abundance on the abundance of questing adult Ixodes scapularis (Acari: Ixodidae). Journal of Medical Entomology 36:376-381.

Gladfelter, H. L. 1978. Movement and home range of deer as determined by radio telemetry. Iowa Wildlife Resources Bulletin 23. Iowa Department of Natural Resources, Boone, USA.

Gladfelter, H. L., J. M. Kienzler, and K. J. Koehler. 1983. Effects of compound bow use on deer hunter success and crippling rates in Iowa. Wildlife Society Bulletin 11:7-13.

Grund, M. D. 1998. Movement patterns and habitat use of an urban whitetailed deer population in Bloomington, Minnesota. Thesis, University of Missouri-Columbia, USA.

Gubanyi, J. A., J. A. Savidge, S. E. Hygnstrom, K. C. VerCauteren, G. W. Garabrandt, and S. P. Korte. 2008. Deer impact on vegetation in natural areas in southeastern Nebraska. Natural Areas Journal 28:121129.

Hansen, L. P., C. M. Nixon, and J. Beringer. 1997. Role of refuges in the dynamics of outlying deer populations: two examples from the agricultural Midwest. Pages 327-345 in W. J. McShea, H. B. Underwood, and J. H. Rappole, editors. The science of overabundance: deer ecology and population management. Smithsonian Institution Press, Washington, D.C., USA.

Hygnstrom, S. E., B. Trindle, and K. C. VerCauteren. 2005. Deer damage management. University of Nebraska-Lincoln Extension NebGuide, Lincoln, USA.

Hygnstrom, S. E., and K. C. VerCauteren. 1995. Deer damage management. University of Nebraska-Lincoln Extension Circular, Lincoln, USA.

Hygnstrom, S. E., and K. C. VerCauteren. 1999. Ecology of white-tailed deer in the Gifford Point Fontenelle Forest area, Nebraska. University of Nebraska-Lincoln, Final Report, Lincoln, USA.

Hygnstrom, S. E., K. C. VerCauteren, S. R. Groepper, G. W. Garabrandt, and J. A. Gubanyi. 2011. Effects of seasons and hunting on space use by female white-tailed deer in a developed landscape in southeastern Nebraska. Wildlife Society Bulletin 35:220-226.

Ishmael, W. E., D. E. Katsma, A. Isaac, and B. K. Bryant. 1995. Livecapture and translocation of suburban white-tailed deer in River Hills, Wisconsin. Proceedings of the Midwest Fish and Wildlife Conference 55:87-96.

Ishmael, W. E., and O. J. Rongstad. 1984. Economics of an urban deerremoval program. Wildlife Society Bulletin 12:394-398.

Jensen, C. H., and G. W. Scotter. 1977. A comparison of twig length and browsed twig methods of determining browse utilization. Journal of Range Management 30:64-67.

Joly, D. O., M. D. Samuel, J. A. Langenberg, J. A. Blanchong, C. A. Batha, R. E. Rolley, D. P. Keane, and C. A. Ribic. 2006. Spatial epidemiology of chronic wasting disease in Wisconsin white-tailed deer. Journal of Wildlife Diseases 42:578-588.

Kilpatrick, H. J., S. M. Spohr, and G. G. Chasko. 1997. A controlled deer hunt on a state-owned coastal reserve in Connecticut: controversies, strategies, and results. Wildlife Society Bulletin 25:451-456.

Kilpatrick, H. J., and W. D. Walter. 1997. Urban deer management: a community vote. Wildlife Society Bulletin 25:388-391.
Mathews, N. E., J. Paul-Murphy, and E. S. Frank. 2005. Evaluation of a trap-sterilize-release program for white-tailed deer management in Highland Park, Illinois, 2002-2005. Report for the Highland Park City Council, Highland Park, USA.

Mathews, N. E., and W. F. Porter. 1993. Effect of social structure on genetic structure of free-ranging white-tailed deer in the Adirondack Mountains. Journal of Mammalogy 74:33-43.

McPhillips, K. B., R. L. Linder, and W. A. Wentz. 1985. Nonreporting, success, and wounding by South Dakota deer bowhunters. Wildlife Society Bulletin 13:395-398.

Miller, R., J. B. Kaneene, S. M. Schmitt, D. P. Lusch, and S. D. Fitzgerald. 2007. Spatial analysis of Mycobacterium bovis infection in white-tailed deer (Odocoileus virginianus) in Michigan, USA. Preventive Veterinary Medicine 82:111-122.

Nebraska Game and Parks Commission. 2011. Record number of deer harvested in Nebraska. <http://outdoornebraska.ne.gov/hunting/guides/ biggame/deer/BGdeer.asp > . Accessed 22 Jul 2011.

O'Bryan, M. K., and D. R. McCullough. 1985. Survival of black-tailed deer following relocation in California. Journal of Wildlife Management 49:115-119.

Porter, W. F., N. E. Mathews, H. B. Underwood, R. W. Sage, and D. F. Behrend. 1991. Social organization in deer: implications for localized management. Environmental Management 15:809-814.

Rupiper, J. 2003. The impact of white-tailed deer (Odocoileus virginianus) on vegetation of urban forests in eastern Nebraska. Thesis, University of Nebraska-Omaha, Omaha, USA.

Seaman, D. E., J. J. Millspaugh, B. J. Kernohan, G. C. Brundige, K. J. Raedeke, and R. A. Gitzen. 1999. Effects of sample size on kernel home range estimates. Journal of Wildlife Management 63:739-747.

Stromayer, K. A. K., and R. J. Warren. 1997. Are overabundant deer herds in the eastern United States creating alternate stable states in forest plant communities? Wildlife Society Bulletin 25:227-234.

Sudharsan, K., S. J. Riley, and H. I. Campa. 2009. Relative risks of deervehicle collisions along road types in southeast Michigan. Human Dimensions of Wildlife 14:341-352.

Swihart, R. K., P. M. Picone, A. J. DeNicola, and L. Cornicelli. 1995. Ecology of urban and suburban white-tailed deer. Pages 35-44 in J. B. McAninch, editor. Urban deer: a manageable resource? Proceedings of a symposium held at the 55th Midwest Fish and Wildlife Conference, St. Louis, Missouri, USA.

US Department of Labor. 2011. Bureau of Labor Statistics, consumer price index. <http://www.bls.gov/cpi>. Accessed 21 Jul 2011.

VerCauteren, K. C. 1993. Home range and movement characteristics of female white-tailed deer at DeSoto National Wildlife Refuge. Thesis, University of Nebraska-Lincoln, USA.

VerCauteren, K. C., J. Beringer, and S. E. Hygnstrom. 1997. Use of nettedcage traps in population management and research of urban white-tailed deer. Proceedings of the Great Plains Wildlife Damage Control Workshop 13:138-142.

VerCauteren, K. C., and S. E. Hygnstrom. 2000. Deer population management through hunting in a suburban nature area in eastern Nebraska. Vertebrate Pest Conference 19:101-106.

Waller, D. M., and W. S. Alverson. 1997. The white-tailed deer: a keystone herbivore. Wildlife Society Bulletin 25:217-226.

White, G. C., and R. A. Garrott. 1990. Analysis of wildlife radio-tracking data. Academic Press, San Diego, California, USA.

Associate Editor: Nielsen. 